\title{
PENGARUH PENERAPAN MANAJEMEN MUTU ISO 9001:2008 DAN KEPEMIMPINAN TERHADAP KUALITAS PELAYANAN SMK NEGERI 2 KABUPATEN TANGERANG
}

\author{
Danang Rifai ${ }^{1}$ \\ Syamsul Fallah ${ }^{2}$ \\ Mira Purwasari ${ }^{3}$ \\ Dosen STMIK Raharjal, Guru SMKN 2 Kab. Tangerang ${ }^{2}$, STMIK Raharja Jurusan \\ Sistem Informasi ${ }^{3}$ \\ Jl. Jendral Sudirman No. 40, Modern Cikokol, Tangerang ${ }^{1,2,3}$ \\ Email : danang.rifai@raharja.info ${ }^{1)}$, fawaj.nurfalah@gmail.com ${ }^{2}$, mira@raharja.info ${ }^{3)}$
}

\begin{abstract}
ABSTRAK
Penelitian ini berjudul pengaruh penerapan manajemen mutu ISO 9001:2008 pada kepemimpinan dan kualitas pelayanan di SMK Negeri 2 Kabupaten Tangerang. Rumusan masalah penelitian ini adalah apakah terdapat pengaruh penerapan ISO 9001:2008 dan kepemimpinan kepala sekolah terhadap kualitas pelayanan di SMK Negeri 2 Kabupaten Tangerang. Sedangkan tujuaannya adalah ingin mengetahui pengaruh penerapan ISO 9001:2008 dan kinerja guru terhadap kualitas pelayanan di SMK Negeri 2 Kabupaten Tangerang. Penelitian ini menggunakan metode survey dengan teknik korelasional, jumlah sampel 350 orang, obyek penelitian siswa, guru dan karyawan SMK Negeri 2 Kabupaten Tangerang. Hasil dari penelitian adalah terdapat pengaruh yang signifikan menejemen mutu ISO 9001:2008 dan kepemimpinan kepala sekolah secara bersama-sama terhadap terhadap kualitas layanan di SMK Negeri 2 Kabupaten Tangerang. Hal tersebut dibuktikan dengan (sig) sebesar 0,000<0,05 dan $F_{\text {hitung }}$ sebesar 62,233. Terdapat pengaruh yang signifikan menejemen mutu ISO 9001:2008 terhadap terhadap kualitas layanan di SMK Negeri 2 Kabupaten Tangerang.. Hal ini dibuktikan dengan nilai Sig $=0.000<0,05$ dan $\boldsymbol{t}_{\text {hitung }}=5$ 5,933. Terdapat pengaruh yang signifikan kepemimpinan Kepala Sekolah terhadap terhadap kualitas layanan di SMK Negeri 2 Kabupaten Tangerang. Dan dibuktikan dengan nilai Sig $=0.001<0,05$ dan $\boldsymbol{t}_{\text {hitung }}=3,396$.
\end{abstract}

Kata kunci : Manajemen Mutu ISO 9001:2008, Kepemimpinan dan Kualitas Layanan.

\begin{abstract}
This research entitled the influence of the implementation of ISO 9001:2008 quality management on leadership and service quality in SMK Negeri 2 Kabupaten Tangerang. The formulation of this research problem is whether there is influence of the implementation of ISO 9001: 2008 and principal leadership on the quality of service in SMK Negeri 2 Tangerang Regency. While tujuaannya is wanted to know the effect of the implementation of ISO 9001: 2008 and teacher performance on service quality in SMK Negeri 2 Kabupaten Tangerang. This research used survey method with correlation technique, sample size 350 people, student research object, teacher and employee of SMK Negeri 2 Kabupaten Tangerang. The result of this research is that there is a significant effect of quality management of ISO 9001: 2008 and principal leadership together towards the quality of service in SMK Negeri 2 Kabupaten Tangerang. This is evidenced by (sig) of $0.000<0.05$ and Fcount of 62.233. There is a significant effect of quality management of ISO 9001: 2008 on the quality of service in SMK Negeri 2 Kabupaten Tangerang. This is evidenced by the value of Sig $=0.000<0.05$ and tcount $=5.933$. There is a significant influence of Headmaster's leadership on the quality of service in SMK Negeri 2 Kabupaten Tangerang. And proved by the value of Sig $=0.001<0.05$ and tcount $=3.396$.
\end{abstract}

Keywords : Quality Management ISO 9001: 2008, Leadership and Service Quality. 


\section{PENDAHULUAN}

Sekolah Menengah Kejuruan (SMK) merupakan salah satu institusi pendidikan formal yang mempunyai visi secara langsung mencetak sumber daya manusia yang siap kerja. Peranan SMK dipertegas oleh Kementerian Pendidikan Nasional Tahun 2011 yaitu SMK mempunyai visi, yaitu terwujudnya SMK bertaraf internasional, menghasilkan tamatan yang memiliki jati diri bangsa, mampu mengembangkan keunggulan local dan bersaing di pasar global. Dengan visi SMK tersebut, pendidikan nasional mempunyai misi sebagai berikut: meningkatkan profesionalisme dan good governance SMK sebagai pusat pembudayaan kompetensi, meningkatkan mutu penyelenggaraan pendidikan, membangun dan memberdayakan SMK bertaraf Internasional sehingga menghasilkan lulusan yang memiliki jati diri bangsa dan keunggulan kompetitif di pasar nasional dan global, memberdayakan SMK untuk mengembangkan potensi lokal menjadi keunggulan komparatif, memberdayakan SMK untuk mengembangkan kerjasama dengan industri, PPPG, LPMP, dan berbagai lembaga terkait, dan meningkatkan perluasan dan pemerataan akses pendidikan kejuruan yang bermutu. Berdasarkan visi dan misi SMK tersebut, SMK memiliki tujuan sebagai berikut: mewujudkan lembaga pendidikan kejuruan yang akuntabel sebagai pusat pembudayaan kompetensi berstandar nasional, mendidik sumber daya manusia yang mempunyai etos kerja dan kompetensi berstandar internasional, memberikan berbagai layanan pendidikan kejuruan yang fleksibel secara terintegrasi antara jalur dan jenjang pendidikan, memperluas layanan dan pemerataan mutu pendidikan kejuruan dan mengangkat keunggulan lokal sebagai modal daya saing bangsa. Mutu adalah gambaran dan karakteristik menyeluruh dari barang atau jasa yang menunjukkan kemampuanya dalam memuaskan kebutuhan yang diharapkan. Mutu merupakan kunci utama sekolah atau institusi untuk meraih keberhasilan. Mutu sebuah sekolah dapat diukur dari kualitas pelayanan. Maka sekolah dalam rangka meningkatkan mutu menerapkan Sistem Manajemen Mutu ISO 9001:2008 disingkat SMM ISO 9001. ISO yang merupakan singkatan dari International Standardization Organization adalah federasi badan-badan standarisasi seluruh dunia. ISO didirikan pada tanggal 23 Februrari 1947 di Jenewa, Switzerland. ISO 9001 merupakan salah satu bagian dalam ISO. Pada tanggal 14 November 2008, ISO telah merilis edisi terbaru dari ISO 9001 yaitu ISO 9001:2008. ISO 9001 adalah suatu standar internasional untuk system manajemen kualitas. ISO 9001 menetapkan persyaratan-persyaratan dan rekomendasi untuk desain dan penilaian dari suatu system manajemen kualitas yang bertujuan untuk menjamin bahwa organisasi akan memberikan suatu produk yang memenuhi persyaratanpersyaratan yang ditetapkan. ISO yang merupakan singkatan dari International Standardization Organization adalah federasi badan - badan standarisasi seluruh dunia. ISO didirikan pada tanggal 23 Februrari 1947 di Jenewa, Switzerland. ISO 9001 merupakan salah satu bagian dalam ISO. Pada tanggal 14 November 2008, ISO telah merilis edisi terbaru dari ISO 9001 yaitu ISO $9001: 2008$.

ISO 9001 adalah suatu standar internasional untuk system manajemen kualitas. ISO 9001 menetapkan persyaratan - persyaratan dan rekomendasi untuk desain dan penilaian dari suatu system manajemen kualitas yang bertujuan untuk menjamin bahwa organisasi akan memberikan suatu produk yang memenuhi persyaratan - persyaratan yang ditetapkan. Persyaratan - persyaratan yang ditetapkan ini dapat merupakan kebutuhan spesifik dari pelanggan. Organisasi yang dikontrak bertanggung jawab menjamin kualitas dari produk - produk tertentu yang merupakan kebutuhan dari pasar tertentu. Persyaratan - persyaratan dan rekomendasi dalam ISO 9001 diterapkan pada manajemen organisasi yang memasok produk sehingga akan mempengaruhi bagaimana 
produk itu didesain, diproduksi, dirakit dan ditawarkan. Sistem manajemen mutu ISO 9001 : 2008 berlandaskan pada delapan prinsip manajemen mutu. Prinsip - prinsip itu digunakan sebagai kerangka kerja yang membimbing organisasi menuju peningkatan kinerja. Prinsip - prinsip itu antaralain adalah (1) Fokus pada pelanggan (2) Kepemimpinan (3) Keterlibatan orang - orang (4) Pendekatan proses (5) Pendekatan sistem terhadap manajemen (6) Peningkatan terus menerus (7) Pendekatan faktual dalam pembuatan keputusan (8) Hubungan pemasok yang saling menguntungkan. Berdasarkan salah satu prinsip dari sistem manajemen mutu ISO 9001 : 2008 yaitu fokus pada pelanggan yang dapat diartikan kepuasan pelanggan. Sistem manajamen mutu ISO 9001 : 2008 memperhatikan bahwa pelanggan memegang peranan yang sangat penting dalam menetapkan persyaratan - persyaratan sebagai masukan Indikator dari kepuasan pelanggan dapat dilihat dari kualitas pelayanan. Vincent Gasperz mendefinisikan bahwa kualitas pelayanan adalah segala sesuatu yang memenuhi kebutuhan pelanggan ( meeting the need of customer). Kepuasan pelanggan lebih bersifat relatif karena persepsi kepuasan pada suatu hal antara pelanggan yang satu dengan pelanggan yang lain berbeda. Berdasarkan pengamatan yang telah dilakukan, terdapat beberapa permasalahan antara lain pendapat berbeda dari para siswa mengenai cara mengajar beberapa guru. Ada siswa yang mengatakan bahwa cara mengajar guru sudah dapat menarik perhatian siswa dan siswa yang lain mengeluhkan tentang cara mengajar dari guru tersebut. Disamping masalah yang tersebut diatas, ada beberapa permasalahan lain yaitu terdapat perbedaan pendapat tentang layanan adminstrasi dan terdapat perbedaan pendapat antara siswa tentang layanan teknisi yang ada disekolah. Pada dasarnya SMK Negeri 2 Kabupaten Tangerang memiliki peningkatan mutu yang sangat pesat, yang ditandai dengan banyaknya prestasi yang telah diraih siswa SMK Negeri 2 Kabupaten Tangerang dalam kompetisi antar SMK, selain itu juga terbukti dengan banyaknya lulusan SMK Negeri 2 Kabupaten Tangerang yang mendapatkan pekerjaan sesuai dengan kompetensinya hanya saja diperlukan adanya peningkatan pelayanan agar mutu sekolah lebih meningkat. Peneliti ingin menganalisa bahwa penerapan sistem manajemen mutu ISO 9001:2008 mengakibatkan kualitas bidang pelayanan administrasi, pembelajaran/kinerja guru dan bengkel atau teknisi. Atas dasar permasalahan tersebut peneliti merumuskan permasalahan:

1. Apakah terdapat pengaruh penerapan ISO:9001:2008 dan kepemimpinan kepala sekolah terhadap kualitas pelayanan di SMK Negeri 2 Kabupaten Tangerang?

2. Apakah terdapat pengaruh penerapan ISO:9001:2008 dan kinerja guruterhadap kualitas pelayanan di SMK Negeri 2 Kabupaten Tangerang?

3. Apakah terdapat pengaruh kepemimpinan kepala sekolah terhadap kualitas pelayanan di SMK Negeri 2 Kabupaten Tangerang?

\section{Metode}

Metode yang digunakan dalam penelitian ini adalah metode survey dengan teknik korelasional. Metode ini memberikan deskripsi tentang variabel-variabel yang akan diteliti dan menyelidiki hubungan antar variabel, diantaranya adalah hubungan antara variabel Kualitas Pelayanan di SMK Negeri 2 Kabupaten Tangerang (Y), Penerapan ISO 9001:2008 (X). Dalam penelitian ini data dijaring dari sampel yang berjumlah 340 siswa kelas XI Sekolah Menengah Kejuruan Negeri Kabupaten Tangerang. Untuk mengetahui terdapat pengaruh atau tidak Penerapan ISO 9001:2008 (X1) terhadap Kualitas Pelayanan di SMK Negeri 2 Kabupaten Tangerang (Y) digunakan regresi sederhana. Populasi merupakan wilayah generalisasi yang terdiri atas objek atau subjek yang mempunyai 
kualitas dan karakteristik tertentu yang ditetapkan oleh peneliti untuk dipelajari dan kemudian ditarik kesimpulannya (Sugiyono, 2009: 117). Populasi dalam penelitian ini adalah seluruh warga SMK Negeri 2 Kabupaten Tangerang yang berjumlah 1597 siswa Mengingat banyaknya populasi, maka dalam penelitian ini diambil 150 siswa SMK tingkat II sebagai sampel karena siswa tingkat II lebih memiliki pengetahuan dalam memberikan keterangan sedangkan siswa kelas I belum memahami keadaan pelayanan di sekolah dan siswa tingkat III dikonsentrasikan untuk persiapan menghadapi ujian nasional. Oleh karena itu, penentuan sampel dalam penelitian ini menggunakan purposive Sampling. Sampel menurut Suharsimi Arikunto adalah sebagian atau wakil populasi yang diteliti (2000: 109). Besar kecilnya pengambilan sampel agar dapat menjadi cermin dari populasi, Suharsimi mengatakan bahwa "Jika jumlah subyeknya kurang dari 100, lebih baik diambil semua sehingga penelitiannya merupakan penelitian populasi. Tetapi jika jumlah subyeknya besar (lebih dari 100) maka sampel dapat diambil 10-15\% atau 20-25\% atau lebih. (Suharsimi Arikunto, 2002:112). Besarnya sampel dalam penelitian ini mengacu pada tabel yang dikembangkan Isaac dan Michael (Sugiyono, 2006:128). Besarnya sampel yang di inginkan mempunyai taraf kesalahan 5\%. Maka jumlah sampel yang diambil yaitu 340 .

Tabel 1 Sample Proposional

\begin{tabular}{|c|c|c|c|}
\hline No & Keterangan & Populasi & Sample \\
\hline 1 & Guru & 104 & 10 \\
\hline 2 & Siswa & 2.200 & 330 \\
\hline Jumlah & & 2.304 & 340 \\
\hline
\end{tabular}

\section{Hasil dan Pembahasan}

Dalam deskripsi data penelitian ini akan dikemukakan berbagai hasil penelitian dari data yang diperoleh, yang meliputi: skor tertinggi, skor terendah, rerata (mean), modus, median, ragam/varians dan simpangan baku/standar deviasi. Dalam pengolahan data yang diperoleh, peneliti melakukan pengolahan data dengan bantuan SPSS 20 dengan hasil sebagai berikut :

\section{Penerapan Menejemen Mutu ISO 9001:2008}

Berdasarkan perhitungan dengan bantuan SPSS 20 diperoleh hasil pengolahan data sebagai berikut :

Tabel 2

Diskripsi Data Penerapan Menejemen Mutu ISO 9001:2008

\begin{tabular}{|c|c|c|}
\hline \multicolumn{3}{|c|}{ Statistics } \\
\hline \multicolumn{3}{|c|}{ Penerapan Menejemen Mutu ISO 9001:2008 } \\
\hline \multirow[t]{2}{*}{$\mathrm{N}$} & Valid & 350 \\
\hline & $\begin{array}{l}\text { Missin } \\
\mathrm{g}\end{array}$ & 0 \\
\hline \multicolumn{2}{|c|}{ Mean } & 115.56 \\
\hline \multicolumn{2}{|c|}{ Median } & 114.00 \\
\hline \multicolumn{2}{|c|}{ Mode } & 113 \\
\hline \multicolumn{2}{|c|}{ Std. Deviation } & 27.426 \\
\hline \multicolumn{2}{|c|}{ Variance } & 752.161 \\
\hline \multicolumn{2}{|c|}{ Range } & 108 \\
\hline \multicolumn{2}{|c|}{ Minimum } & 54 \\
\hline
\end{tabular}




\begin{tabular}{|l|r|}
\hline Maximum & 162 \\
\hline Sum & 40445 \\
\hline
\end{tabular}

Untuk mendapatkan gambaran tentang kecenderungan Penerapan Menejemen Mutu ISO 9001:2008 di Sekolah Menengah Kejuruan (SMK) Negeri 2 Kabupaten Tangerang dengan mengkatagorikan nilai rerata observasi terhadap pedoman skala lima. Sebelumnya ditentukan terlebih dahulu rerata ideal (Mi) dan standar Deviasi ideal (SDi).

Mi $($ rerata ideal $)=\frac{1}{2}(162+54)=108$

SDi $($ standar deviasi ideal $)=\frac{1}{6}(162-54)=18$

Jadi didapat pedoman konversi skala lima untuk data tentang Penerapan Menejemen Mutu ISO 9001:2008, sebagai berikut:

$$
\begin{array}{ll}
\bar{X}>140,4 & =\text { sangat tinggi } \\
118,8<\bar{X} \leq 140,4 & =\text { tinggi } \\
97,2<\bar{X} \leq 118,8 & =\text { sedang } \\
75,6<\bar{X} \leq 97,2 & =\text { rendah } \\
\bar{X} \leq 75,6 & =\text { sangat rendah }
\end{array}
$$

Dengan memperhatikan rerata skor penerapan menejemen mutu ISO 9001:2008 yang bernilai 115,56 dan pedoman koversi skala lima, maka terlihat rerata tersebut terletak pada rentang $97,2<\bar{X} \leq 118,8$. Ini mengindikasikan bahwa penerapan menejemen mutu ISO 9001:2008 (SMK) Sekolah Menengah Kejuruan Negeri 2 Kabupaten Tangerang pada katagori sedang. Selanjutnya melihat gambar histogram dari skor penerapan Menejemen Mutu ISO 9001:2008 sebagai berikut :

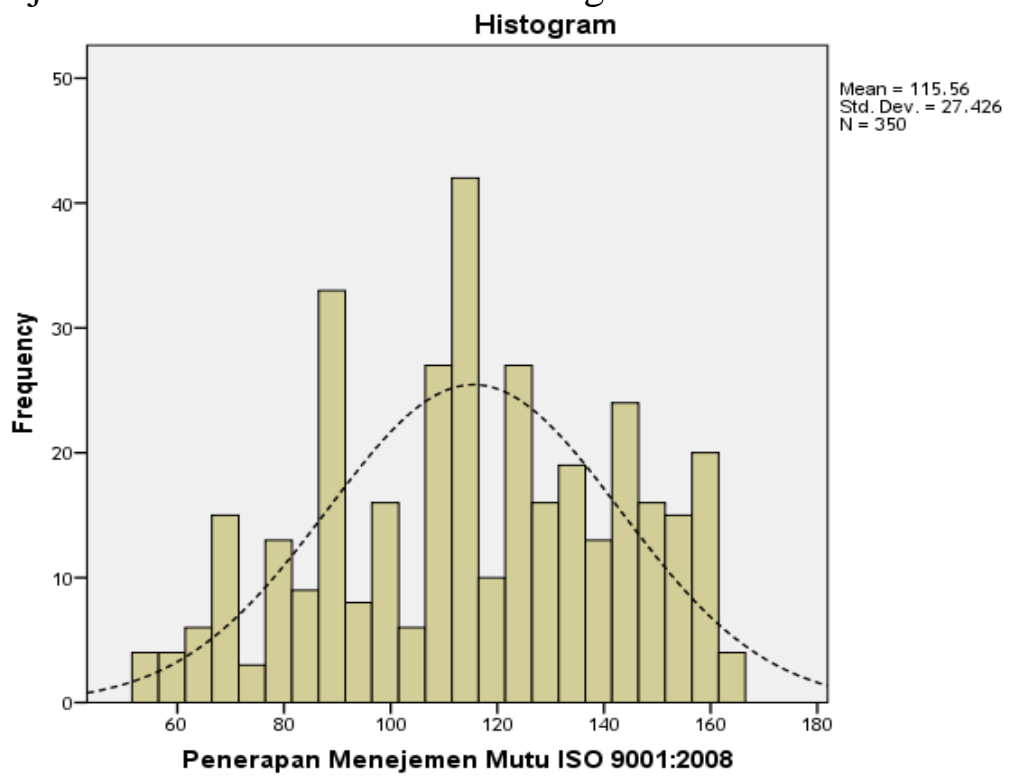

Gambar. 1

Histogram merupakan gambaran dalam bentuk batang yang menunjukkan frekuensi dari masing-masing data. Poligon menunjukan bentuk mendekati kurva normal, hal ini menunjukkan bahwa data yang diperoleh dalam penelitian ini berdistribusi normal, karena bentuk dari kurva mendekati bentuk kurva normal. 


\section{Kepemimpinan Kepala Sekolah.}

Berdasarkan perhitungan dengan bantuan SPSS 20 diperoleh hasil pengolahan data sebagai berikut :

Tabel 4.2

Dsikripsi Data Kepemimpinan Kepala Sekolah

\begin{tabular}{|c|c|c|}
\hline \multicolumn{3}{|c|}{ Statistics } \\
\hline \multicolumn{3}{|c|}{ Kepemimpinan Kepala Sekolah } \\
\hline \multirow[t]{2}{*}{$\mathrm{N}$} & Valid & 350 \\
\hline & Missing & 0 \\
\hline \multicolumn{2}{|c|}{ Mean } & 61.31 \\
\hline \multicolumn{2}{|c|}{ Median } & 60.50 \\
\hline \multicolumn{2}{|c|}{ Mode } & 80 \\
\hline \multicolumn{2}{|c|}{ Std. Deviation } & 15.755 \\
\hline \multicolumn{2}{|c|}{ Variance } & 248.224 \\
\hline \multicolumn{2}{|c|}{ Range } & 60 \\
\hline \multicolumn{2}{|c|}{ Minimum } & 28 \\
\hline \multicolumn{2}{|c|}{ Maximum } & 88 \\
\hline \multicolumn{2}{|c|}{ Sum } & 21457 \\
\hline
\end{tabular}

Untuk mendapatkan gambaran tentang kecenderungan Kepemimpinan Kepala Sekolah di Sekolah Menengah Kejuruan (SMK) Negeri 2 Kabupaten Tangerang dengan mengkatagorikan nilai rerata observasi terhadap pedoman skala lima. Sebelumnya ditentukan terlebih dahulu rerata ideal (Mi) dan standar Deviasi ideal (SDi).

Mi $($ rerata ideal $)=\frac{1}{2}(88+28)=58$

SDi $($ standar deviasi ideal $)=\frac{1}{6}(88-28)=10$

Jadi didapat pedoman konversi skala lima untuk data tentang kepemimpinan Kepala Sekolah, sebagai berikut:

$$
\begin{array}{ll}
\bar{X}>76 & =\text { sangat tinggi } \\
64<\bar{X} \leq 76 & =\text { tinggi } \\
52<\bar{X} \leq 64 & =\text { sedang } \\
40<\bar{X} \leq 52 & =\text { rendah } \\
\bar{X} \leq 40 & =\text { sangat rendah }
\end{array}
$$

Dengan memperhatikan rerata skor Kepemimpinan Kepala Sekolah yang bernilai 61,31 dan pedoman koversi skala lima, maka terlihat rerata tersebut terletak pada rentang $52<\bar{x} \leq 64$. Ini mengindikasikan bahwa Kepemimpinan Kepala Sekolah Sekolah Menengah Kejuruan Negeri 2 Kabupaten Tangerang pada katagori sedang. Selanjutnya melihat gambar histogram dari skor Kepemimpinan Kepala Sekolah sebagai berikut : 


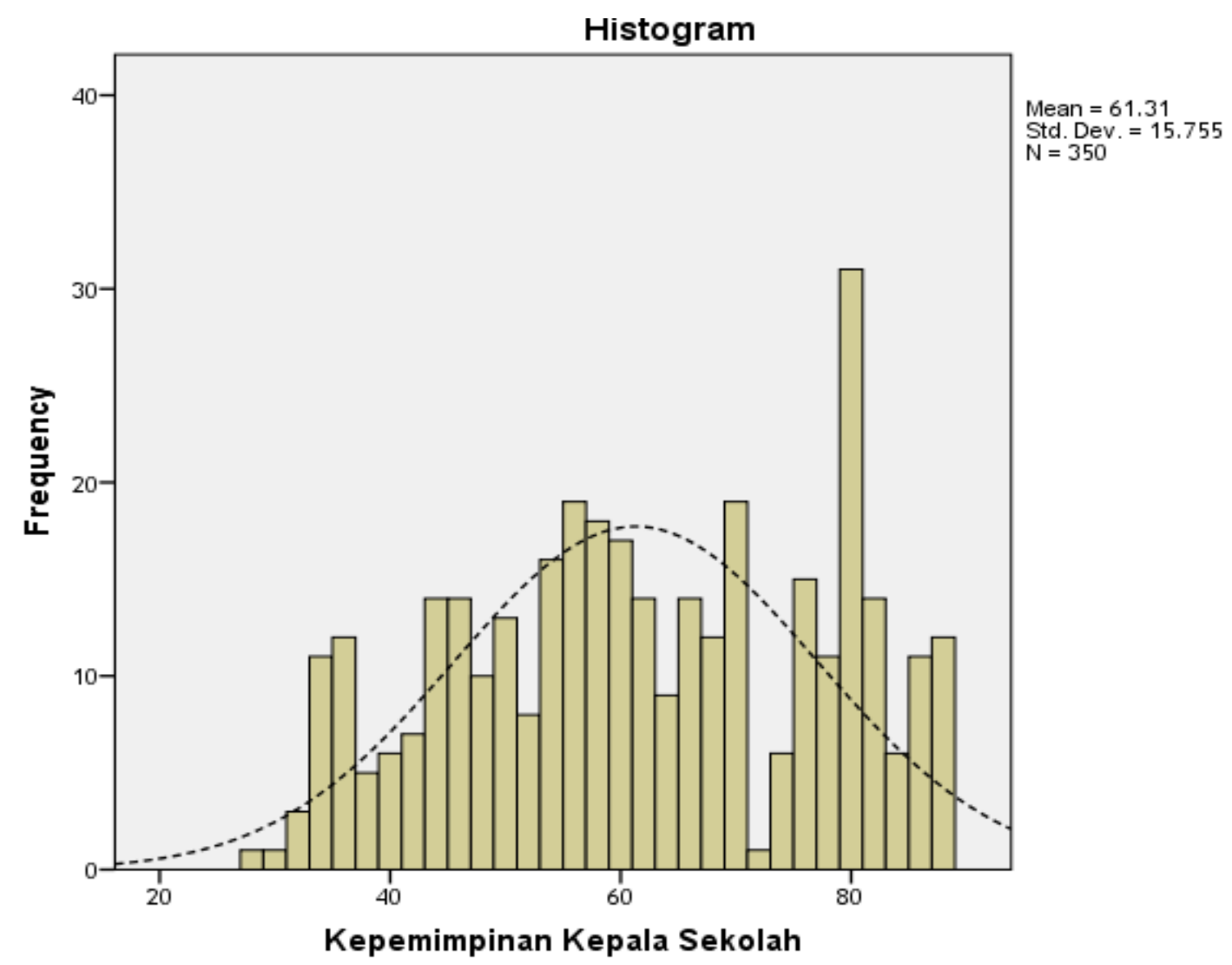

Gambar 4.2

Histogram merupakan gambaran dalam bentuk batang yang menunjukkan frekuensi dari masing-masing data. Poligon menunjukan bentuk mendekati kurva normal, hal ini menunjukkan bahwa data yang diperoleh dalam penelitian ini berdistribusi normal, karena bentuk dari kurva mendekati bentuk kurva normal.

\section{Kualitas Pelayanan di SMK Negeri 2 Kabupaten Tangerang.}

Berdasarkan perhitungan dengan bantuan SPSS 20 diperoleh hasil pengolahan data sebagai berikut :

Tabel 3

Diskripsi Data Kualitas Pelayanan di SMK Negeri 2 Kabupaten Tangerang

\begin{tabular}{|c|c|c|}
\hline \multicolumn{3}{|c|}{ Statistics } \\
\hline \multicolumn{3}{|c|}{ Kualitas Pelayanan } \\
\hline \multirow[t]{2}{*}{$\mathrm{N}$} & Valid & 350 \\
\hline & Missing & 0 \\
\hline \multicolumn{2}{|c|}{ Mean } & 107.96 \\
\hline \multicolumn{2}{|c|}{ Median } & 110.00 \\
\hline \multicolumn{2}{|c|}{ Mode } & 112 \\
\hline \multicolumn{2}{|c|}{ Std. Deviation } & 6.802 \\
\hline \multicolumn{2}{|c|}{ Variance } & 46.262 \\
\hline \multicolumn{2}{|c|}{ Range } & 38 \\
\hline \multicolumn{2}{|c|}{ Minimum } & 82 \\
\hline \multicolumn{2}{|c|}{ Maximum } & 120 \\
\hline \multicolumn{2}{|c|}{ Sum } & 37786 \\
\hline
\end{tabular}


Untuk mendapatkan gambaran tentang kecenderungan kualitas layanan di Sekolah Menengah Kejuruan (SMK) Negeri 2 Kabupaten Tangerang dengan mengkatagorikan nilai rerata observasi terhadap pedoman skala lima. Sebelumnya ditentukan terlebih dahulu rerata ideal (Mi) dan standar Deviasi ideal (SDi).

$\operatorname{Mi}($ rerata ideal $)=\frac{1}{2}(120+82)=101$

SDi $($ standar deviasi ideal $)=\frac{1}{6}(120-82)=6,33$

Jadi didapat pedoman konversi skala lima untuk data tentang kualitas layanan, sebagai berikut:

$$
\begin{array}{ll}
\bar{X}>112,4 & =\text { sangat tinggi } \\
104,8<\bar{X} \leq 112,4 & =\text { tinggi } \\
97,2<\bar{X} \leq 104,8 & =\text { sedang } \\
89,6<\bar{X} \leq 97,2 & =\text { rendah } \\
\bar{X} \leq 89,6 & =\text { sangat rendah }
\end{array}
$$

Dengan memperhatikan rerata skor kualitas layanan yang bernilai 107,96 dan pedoman koversi skala lima, maka terlihat rerata tersebut terletak pada rentang $104,8<\leq$

112,4.Ini mengindikasikan bahwa kualitas layanan di (SMK) Sekolah Menengah Kejuruan Negeri 2 Kabupaten Tangerang pada katagori tinggi. Selanjutnya melihat gambar histogram dari skor Kualitas Pelayanan di SMK Negeri 2 Kabupaten Tangerang sebagai berikut :

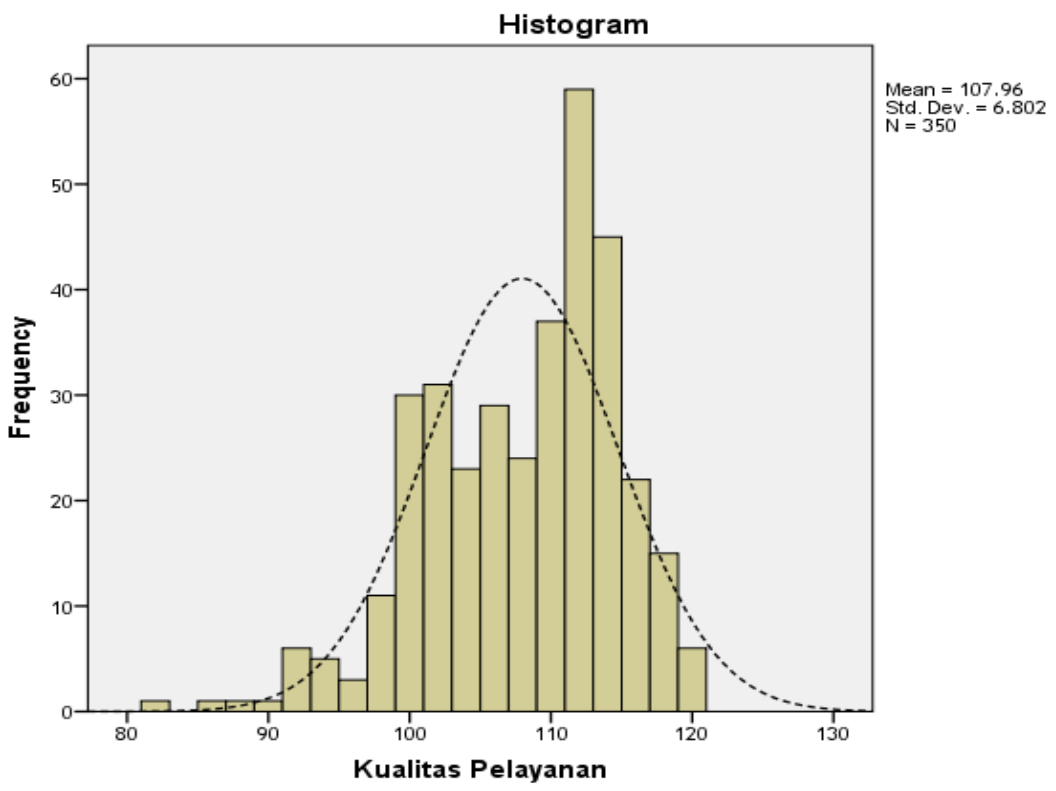

Gambar. 2

Histogram merupakan gambaran dalam bentuk batang yang menunjukkan frekuensi dari masing-masing data. Poligon menunjukan bentuk mendekati kurva normal, hal ini menunjukkan bahwa data yang diperoleh dalam penelitian ini berdistribusi normal, karena bentuk dari kurva mendekati bentuk kurva normal. Uji normalitas dilakukan untuk 
mengetahui apakah data yang diperoleh peneliti berasala dari populasi berdistribusi normal atau tidak. Hal ini dilakukan sebagai syarat jika pengujian dilakukan dengan menggunakan statistik parametrik. Dalam melakukan uji normalitas peneliti menggunakan SPSS 20 sebagai alat bantu. Dalam hal ini peneliti melakukan pengujian dengan menggunakan Kolmogov Smirnov.

\section{Uji Prasyarat}

\section{Penerapan Manajemen Mutu ISO 9001:2008}

Hasil pengujian dengan menggunakan SPSS 20 diperoleh :

Tabel 4

Uji Normalitas Penerapan Menejemen Mutu ISO 9001:2008

\begin{tabular}{|c|c|c|}
\hline \multicolumn{3}{|c|}{ One-Sample Kolmogorov-Smirnov Test } \\
\hline & & $\begin{array}{l}\text { Penerapan Menejemen Mutu ISO } \\
9001: 2008\end{array}$ \\
\hline \multicolumn{2}{|l|}{$\mathrm{N}$} & 350 \\
\hline \multirow{2}{*}{$\begin{array}{l}\text { Normal } \\
\text { Parameters }\end{array}$} & Mean & 115.56 \\
\hline & Std. Deviation & 27.426 \\
\hline \multirow{3}{*}{$\begin{array}{l}\text { Most } \\
\text { Extreme } \\
\text { Differences }\end{array}$} & Absolute & .068 \\
\hline & Positive & .066 \\
\hline & Negative & -.068 \\
\hline \multicolumn{2}{|c|}{ Kolmogorov-Smirnov Z } & 1.270 \\
\hline \multicolumn{2}{|c|}{ Asymp. Sig. (2-tailed) } & .079 \\
\hline \multicolumn{3}{|c|}{ a. Test distribution is Normal. } \\
\hline \multicolumn{3}{|c|}{ b. Calculated from data. } \\
\hline
\end{tabular}

Interpretasi : Dalam menginterpretasikan data hasil uji normalitas kita lihat kolom minat membaca, Terdapat nilai Kosmogorov Smirnov $=1,270$ dengan probabilitas 0,079 (Asymp. Sig. (2-tailed)). Persyaratan data berdistribusi normal jika probabilitas atau $\mathrm{p}>$ 0,05 pada uji normalitas dengan Kolmogorov Smirnov. Oleh karena nilai $\mathrm{p}=0,079$, atau $\mathrm{p}>0,05$, maka $\mathrm{H}_{0}$ diterima dan $\mathrm{H}_{1}$ ditolak. Artinya data minat membaca berasal dari populasi yang berdistribusi normal.

\section{Kualitas Pelayanan di SMK Negeri 2 Kabupaten Tangerang}

Dengan bantuan SPSS 20 diperoleh hasil pengujian nomarlitas sebagai berikut :

Tabel 5.

Uji Normalitas Kualitas Pelayanan di SMK Negeri 2 Kabupaten Tangerang

\begin{tabular}{|c|c|c|}
\hline \multicolumn{3}{|c|}{ One-Sample Kolmogorov-Smirnov Test } \\
\hline & & Kualitas Pelayanan \\
\hline \multicolumn{2}{|l|}{$\mathrm{N}$} & 350 \\
\hline \multirow{2}{*}{$\begin{array}{l}\text { Normal } \\
\text { Parameters }{ }^{\mathrm{a}, \mathrm{b}}\end{array}$} & Mean & 107.96 \\
\hline & $\begin{array}{l}\text { Std. } \\
\text { Deviation }\end{array}$ & 6.802 \\
\hline \multirow{3}{*}{$\begin{array}{l}\text { Most } \\
\text { Extreme } \\
\text { Differences }\end{array}$} & Absolute & .141 \\
\hline & Positive & .067 \\
\hline & Negative & -.141 \\
\hline
\end{tabular}




\begin{tabular}{|l|r|}
\hline Kolmogorov-Smirnov Z & 2.636 \\
\hline Asymp. Sig. (2-tailed) & .060 \\
\hline \multicolumn{2}{|c|}{ a. Test distribution is Normal. } \\
\hline \multicolumn{2}{|c|}{ b. Calculated from data. } \\
\hline
\end{tabular}

Interpretasi: Dalam menginterpretasikan data hasil uji normalitas kita lihat kolom keterampilan menulis teks prosedural, Terdapat nilai Kosmogorov Smirnov $=2.636$ dengan probabilitas 0,060 (Asymp. Sig. (2-tailed)). Persyaratan data berdistribusi normal jika probabilitas atau $\mathrm{p}>0,05$ pada uji normalitas dengan Kolmogorov Smirnov. Oleh karena nilai $\mathrm{p}=0,060$, atau $\mathrm{p}>0,05$, maka $\mathrm{H}_{0}$ daiterima $\mathrm{H}_{1}$ ditolak, artinya data tentang keterampilan menulis teks prosedural Siswa berasal dari populasi yang berdistribusi normal. Berdasarkan ketiga uji yang dilakukan di atas maka dapat disimpulkan bahwa data dari ketiga variabel penelitian menunjukan berdistribusi normal. Dengan demikian memenuhi syarat uji analisis parametrik.

\begin{tabular}{|c|c|c|c|c|c|c|c|c|c|}
\hline \multirow[b]{3}{*}{ Model } & \multicolumn{9}{|c|}{ Model Summary } \\
\hline & \multirow[b]{2}{*}{$\mathrm{R}$} & \multirow[b]{2}{*}{$\begin{array}{l}\mathrm{R} \\
\text { Square }\end{array}$} & \multirow[b]{2}{*}{$\begin{array}{c}\text { Adjuste } \\
\text { d R } \\
\text { Square }\end{array}$} & \multirow{2}{*}{$\begin{array}{l}\text { Std. } \\
\text { Error of } \\
\text { the } \\
\text { Estimate }\end{array}$} & \multicolumn{5}{|c|}{ Change Statistics } \\
\hline & & & & & $\begin{array}{c}\text { R } \\
\text { Square } \\
\text { Change }\end{array}$ & F Change & df1 & $\mathrm{df} 2$ & $\begin{array}{l}\text { Sig. F } \\
\text { Change }\end{array}$ \\
\hline 1 & $.012^{\mathrm{a}}$ & .000 & -.003 & 6.811 & .000 & .048 & 1 & 348 & .826 \\
\hline
\end{tabular}

a. Predictors: (Constant), Penerapan Menejemen Mutu ISO 9001:2008

ANOVA $^{\mathrm{a}}$

\begin{tabular}{|c|c|c|c|c|c|}
\hline Model & $\begin{array}{c}\text { Sum of } \\
\text { Squares }\end{array}$ & \multicolumn{1}{c|}{ df } & $\begin{array}{c}\text { Mean } \\
\text { Square }\end{array}$ & F & Sig. \\
\hline Regression & 2.242 & 1 & 2.242 & .048 & $.826^{6}$ \\
& & & & & \\
Residual & 16143.198 & 348 & 46.388 & & \\
Total & 16145.440 & 349 & & & \\
\hline
\end{tabular}

a. Dependent Variable: Kualitas Pelayanan

b. Predictors: (Constant), Penerapan Menejemen Mutu ISO 9001:2008

Coefficients $^{\mathrm{a}}$

\begin{tabular}{|c|c|c|c|c|c|}
\hline \multirow[b]{2}{*}{ Model } & \multicolumn{2}{|c|}{$\begin{array}{l}\text { Unstandardized } \\
\text { Coefficients }\end{array}$} & \multirow{2}{*}{$\begin{array}{c}\text { Standardized } \\
\text { Coefficients } \\
\text { Beta }\end{array}$} & \multirow[b]{2}{*}{$t$} & \multirow[b]{2}{*}{ Sig. } \\
\hline & B & $\begin{array}{l}\text { Std. } \\
\text { Error }\end{array}$ & & & \\
\hline (Constant) & 108.298 & 1.579 & & 68.599 & .000 \\
\hline $\begin{array}{l}\text { Penerapan } \\
\text { Menejemen } \\
\text { Mutu ISO } \\
9001: 2008\end{array}$ & -.003 & .013 & -.012 & -.220 & .826 \\
\hline
\end{tabular}


a. Dependent Variable: Kualitas Pelayanan

\section{Pengaruh Penerapan Menejemen Mutu ISO 9001:2008 $\left(X_{1}\right)$ dan Kepemimpinan Kepala Sekolah $\left(\mathrm{X}_{2}\right)$ secara bersama-sama terhadap terhadap Kualitas Pelayanan di SMK Negeri 2 Kabupaten Tangerang (Y)}

Hipotesis pengaruh ini adalah :

$\mathrm{H}_{0}: \beta_{.1}=0$ atau $\beta_{.2}=0$

$\mathrm{H}_{1}: \beta_{.1} \neq 0$ atau $\beta_{.2} \neq 0$;

artinya :

$\mathrm{H}_{0} \quad$ : tidak terdapat pengaruh yang signifikan minat membaca $\left(\mathrm{X}_{1}\right)$ dan Motivasi Belajar $\left(\mathrm{X}_{2}\right)$ secara bersama-sama terhadap Keterampilan Menulis Teks Prosedural (Y)

$\mathrm{H}_{1} \quad$ : terdapat pengaruh yang signifikan minat membaca $\left(\mathrm{X}_{1}\right)$ dan Motivasi Belajar $\left(\mathrm{X}_{2}\right)$ secara bersama-sama terhadap Keterampilan Menulis Teks Prosedural (Y)

Dari tabel 4.9. di atas terlihat bahwa koefisien korelasi ganda pengaruh variabel bebas penerapan manajemen mutu ISO 9001:2008 ( $\left.\mathrm{X}_{1}\right)$ dan Kepemimpinan Kepala Sekolah $\left(\mathrm{X}_{2}\right)$ secara bersama-sama terhadap Kualitas Pelayanan (Y) adalah sebesar 0,824 .

Berdasarkan nilai $\mathrm{R}=0,824$ terlihat besar koefisien korelasi sangat kecil hal ini dapat disimpulkan bahwa penerapan manajemen mutu ISO 9001:2008 dan Kepemimpinan Kepala Sekolah secara bersama-sama terhadap Kualitas Pelayanan tidak signifikan. Sedangkan koefisien determinasinya sebesar 67,8\% menunjukkan bahwa besarnya kontribusi penerapan manajemen mutu ISO 9001:2008 ( $\left.\mathrm{X}_{1}\right)$ dan Kepemimpinan Kepala Sekolah $\left(\mathrm{X}_{2}\right)$ secara bersama-sama terhadap Kualitas Pelayanan (Y) adalah sebesar $67,8 \%$, Meski demikian terdapat beragam faktor lain yang juga berpengaruh terhadap keterampilan menulis teks prosedural, yang nilainya sebesar 32,2 \%.

Sedangkan untuk pengujian hipotesis melalui analisis regresi diperoleh hasil perhitungan terlihat pada Tabel 4.10. dan Tabel 4.11., Dari Tabel 4.11. diperoleh persamaan garis regresi yang merepresentasikan pengaruh variabel $X_{1}$ dan $X_{2}$ terdahap variabel $\mathrm{Y}$, yaitu $=-70,25+0,738 \mathrm{X}_{1}+0,269 \mathrm{X}_{2}$.

Sedangkan pengujian signifikansi garis regresi tersebut adalah dengan memperhatikan hasil perhitungan yang ada pada Tabel 4.11. Menurut ketentuan yang ada, kriteria signifikansi regresi tersebut adalah :

“jika Sig $<0.05$ maka $\mathrm{H}_{0}$ ditolak" atau "jika $\mathrm{F}_{\text {hitung }}>\mathrm{F}_{\text {tabel }}$ maka $\mathrm{H}_{0}$ ditolak", yang berarti bahwa koefisien regresi tersebut signifikan, dengan kata lain terdapat pengaruh yang signifikan variabel bebas $\mathrm{X}_{1}$ dan $\mathrm{X}_{2}$ terhadap variabel terikat $\mathrm{Y}$. Nilai Sig adalah bilangan yang tertera pada kolom Sig dalam Tabel 4.10. Nilai $F_{\text {hitung }}$ adalah bilangan yang tertera pada kolom $\mathrm{F}$ dalam Tabel 4.10. Sedangkan nilai $\mathrm{F}_{\text {tabel }}$ adalah nilai tabel distribusi $\mathrm{F}$ untuk taraf nyata $5 \%$ dengan derajat pembilang $(\mathrm{k})=2$ dan derajat penyebut $(\mathrm{n}-\mathrm{k}-1)$ $=348$ dimana $\mathrm{n}$ adalah banyaknya responden, dan $\mathrm{k}$ adalah banyaknya variabel bebas.

Dari Tabel 4.10. terlihat bahwa nilai Sig $=0.000<0,05$ dan $F_{\text {hitung }}=62,233$, maka $\mathrm{H}_{0}$ ditolak yang berarti bahwa koefisien regresi tersebut signifikan. Dengan kata lain bahwa terdapat pengaruh yang signifikan variabel bebas penerapan manajemen mutu ISO 
9001:2008 $\left(\mathrm{X}_{1}\right)$ dan Kepemimpinan Kepala Sekolah $\left(\mathrm{X}_{2}\right)$ secara bersama-sama terhadap Kualitas Pelayanan (Y).

Dari hasil pengujian korelasi maupun regresi tersebut maka bisa disimpulkan bahwa terdapat pengaruh yang signifikan variabel bebas penerapan manajemen mutu ISO 9001:2008 $\left(\mathrm{X}_{1}\right)$ dan Kepemimpinan Kepala Sekolah $\left(\mathrm{X}_{2}\right)$ secara bersama-sama terhadap Kualitas Pelayanan (Y)

\section{Pengaruh Penerapan Menejemen Mutu ISO 9001:2008 $\left(X_{1}\right)$ terhadap terhadap Kualitas Pelayanan di SMK Negeri 2 Kabupaten Tangerang (Y)}

Hipotesis pengaruh ini adalah :

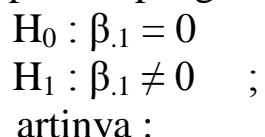

artinya :

$\mathrm{H}_{0} \quad$ : tidak terdapat pengaruh yang signifikan penerapan manajemen mutu ISO 9001:2008 terhadap kualitas pelayanan

$\mathrm{H}_{1} \quad$ : terdapat pengaruh yang signifikan penerapan manajemen mutu ISO 9001:2008 terhadap kualitas pelayanan

Untuk membuktikan hipotesis tersebut adalah dengan memperhatikan nilai/bilangan yang tertera pada kolom t atau kolom Sig untuk baris penerapan manajemen mutu ISO 9001:2008 (Variabel $X_{1}$ ) pada Tabel 4.11. Menurut ketentuan yang ada, kriteria signifikansi regresi tersebut adalah "jika $t_{\text {hitung }}>t_{\text {tabel }}$ maka $\mathrm{H}_{0}$ ditolak" atau "jika Sig < 0,05 maka $\mathrm{H}_{0}$ ditolak", yang berarti bahwa terdapat pengaruh yang signifikan variabel bebas $\mathrm{X}_{1}$ terhadap variabel terikat $\mathrm{Y}$. Nilai Sig adalah bilangan yang tertera pada kolom Sig

Untuk baris penerapan manajemen mutu ISO 9001:2008 (Variabel $\mathrm{X}_{1}$ ) dalam Tabel 4.11. Nilai $t_{\text {hitung }}$ adalah bilangan yang tertera pada kolom $t$ untuk baris minat membaca (Variabel $X_{1}$ ) dalam Tabel 4.11. Sedangkan nilai $t_{\text {tabel }}$ adalah nilai tabel distribusi t untuk taraf nyata 5\% dengan derajat kepercayaan $(\mathrm{df}=\mathrm{n}-2)=348$ dimana $\mathrm{n}$ adalah banyaknya responden.

Dari Tabel 4.11. terlihat bahwa nilai $\operatorname{Sig}=0.000<0,05$ dan $t_{\text {hitung }}=5,993$, maka $\mathrm{H}_{0}$ ditolak yang berarti terdapat pengaruh yang signifikan variabel bebas $\mathrm{X}_{1}$ (penerapan manajemen mutu ISO 9001:2008) terhadap variabel terikat Y (kualitas pelayanan).

Dari hasil pengujian regresi tersebut maka bisa disimpulkan bahwa terdapat pengaruh yang signifikan variabel bebas $\mathrm{X}_{1}$ (penerapan manajemen mutu ISO 9001:2008) terhadap variabel terikat Y (kualitas pelayanan).

Pengaruh Kepemimpinan Kepala Sekolah $\left(X_{2}\right)$ terhadap terhadap Kualitas Pelayanan di SMK Negeri 2 Kabupaten Tangerang (Y)

Hipotesis pengaruh ini adalah :

$\mathrm{H}_{0}: \beta_{.2}=0$

$\mathrm{H}_{1}: \beta_{.2} \neq 0 \quad$;

artinya :

$\mathrm{H}_{0}$ : tidak terdapat pengaruh yang signifikan kepemimpinan Kepala Sekolah terhadap kualitas pelayanan. 
$\mathrm{H}_{1}$ : terdapat pengaruh yang signifikan kepemimpinan Kepala Sekolah terhadap kualitas pelayanan

Untuk membuktikan hipotesis tersebut adalah dengan memperhatikan nilai/bilangan yang tertera pada kolom t atau kolom Sig untuk baris kepemimpinan Kepala Sekolah (Variabel $\mathrm{X}_{2}$ ) pada Tabel 4.11. Menurut ketentuan yang ada, kriteria signifikansi regresi tersebut adalah "jika $t_{\text {hitung }}>t_{\text {tabel }}$ maka $\mathrm{H}_{0}$ ditolak" atau "jika Sig < 0,05 maka $\mathrm{H}_{0}$ ditolak", yang berarti bahwa terdapat pengaruh yang signifikan variabel bebas $\mathrm{X}_{2}$ terhadap variabel terikat $\mathrm{Y}$. Nilai Sig adalah bilangan yang tertera pada kolom Sig untuk baris kepemimpinan Kepala Sekolah (Variabel $\mathrm{X}_{2}$ ) dalam Tabel 4.11. Nilai $t_{\text {hitung }}$ adalah bilangan yang tertera pada kolom $t$ untuk baris motivasi belajar (Variabel $\mathrm{X}_{2}$ ) dalam Tabel 4.11 Sedangkan nilai $\mathrm{t}_{\text {tabel }}$ adalah nilai tabel distribusi $\mathrm{t}$ untuk taraf nyata $5 \%$ dengan derajat kepercayaan $(\mathrm{df}=\mathrm{n}-2)=348$ dimana $\mathrm{n}$ adalah banyaknya responden.

Dari Tabel 4.11. terlihat bahwa nilai Sig $=0.001<0,05$ dan $t_{\text {hitung }}=3,396$, maka $\mathrm{H}_{0}$ diterima yang berarti terdapat pengaruh yang signifikan variabel bebas $\mathrm{X}_{2}$ (kepemimpinan Kepala Sekolah) terhadap variabel terikat Y (kualitas pelayanan).

Dari hasil pengujian regresi tersebut maka bisa disimpulkan bahwa terdapat pengaruh yang signifikan variabel bebas $\mathrm{X}_{2}$ (kepemimpinan Kepala Sekolah) terhadap variabel terikat Y (kualitas pelayanan).

\section{KESIMPULAN}

Dari hasil pengolahan data yang telah dilakukan pada bab sebelumnya, maka dihasilkan beberapa temuan sebagai berikut :

1. Terdapat pengaruh yang signifikan menejemen mutu ISO 9001:2008 dan kepemimpinan Kepala Sekolah secara bersama-sama terhadap terhadap kualitas layanan di SMK Negeri 2 Kabupaten Tangerang. Hal tersebut dibuktikan dengan (sig) sebesar $0,000<0,05$ dan $F_{\text {hitung }}$ sebesar 62,233.

2. Terdapat pengaruh yang signifikan menejemen mutu ISO 9001:2008 terhadap terhadap kualitas layanan di SMK Negeri 2 Kabupaten Tangerang.. Hal ini dibuktikan dengan nilai $\mathbf{S i g}=0.000<0,05$ dan $\mathbf{t}_{\text {hitung }}=5,933$.

3. Terdapat pengaruh yang signifikan kepemimpinan Kepala Sekolah terhadap terhadap kualitas layanan di SMK Negeri 2 Kabupaten Tangerang.. Hal ini dibuktikan dengan nilai Sig $=0.001<0,05$ dan $\mathbf{t}_{\text {hitung }}=3,396$.

Berdasarkan temuan penelitian di atas maka peneliti menyarankan kepada seluruh warga dan pemangku tanggungjawab di SMK Negeri 2 Kabupaten Tangerang untuk:

1. Pelanggang di SMK Negeri 2 Kabupaten Tangerang adalah siswa dan orang tua siswa, mereka perlu mendapatkan layanan belajar dan segala fasilitasnya serta layanan admistrasi .dengan baik, dengan melihat kecenderungan katagori layanan pada level tinggi ini menjadikan bahwa kepercayaan masyarakat masih baik terhadap layanan yang ada di SMK Negeri 2 Kabupaten Tangerang dan perlu ditingkatkan

2. Sekolah beserta pemangku tanggungjawab perlu mempertahankan kualitas layanan, melalui penerapan menejemen mutu ISO 9001:2008 dan kepemimpinan Kepala Sekolah, sebab dari kedua variabel tersebut terbukti secara signifikan memberikan pengaruh terhadap kualitas layanan di SMK Negeri 2 Kabupaten Tangerang. 


\section{DAFTAR PUSTAKA}

[1] Abdul Azis Wahab. (2008). Anatomi organisasi dan kepemimpinan pendidikan: Telaah terhadap organisasi dan pengelolaan organisasi pendidikan. Bandung: Alfabeta.

[2] Abdullah Munir. (2008). Menjadi kepala sekolah efektif. Yogyakarta: Ar-Ruzz Media

[3] E. Mulyasa. (2013). Menjadi kepala sekolah profesional. Bandung: Remaja Rosdakarya Ofseet

[4] Fandy Tjiptono.(2015).Servis, Quality and Satisfaction.Yogyakarta:Andi Offset.

[5] Gasperz, Vincent. (2005). ISO 9001:2000. Jakarta: PT. Niaga Swadaya.

[6] Goult, Roderick S.W. (2009). Introduction to ISO 9001:2008 Handbook. U.S.A: The Victoria Grub,Inc

[7] Hadari Nawawi dan M. Martini Hadari. (2004). Kepemimpinan yang efektif. Yogyakarta: Gadjahmada Press.

[8] Hardiyansyah. (2011). Kualitas Pelayanan Publik. Yogyakarta

[9] Purwadi (2012). ISO 9001 : 2008. Kediri : Media Guru

[10] Riduwan \& Akdon. (2008). Rumus dan Data dalam Analisis Statistika. Bandung :Alfabeta

[11] Sugiyono.(2013). Statistik Untuk Penelitian. Bandung : Alfabeta

[12] Vincent, Gasperz (2006). ISO 9001:2000, and Continual Quality Improvement. Jakarta :

Gramedia Pustaka Utama

[13] Wahyudi. (2009). Kepemimpinan kepala sekolah dalam organisasi pembelajar. Bandung: Alfa Beta.

[14] Wuradji. (2009). The educational leadership (kepemimpinan transformational). Yogyakarata: Gama Media. 